\title{
Virtual Mathematics Kits (VMK): Connecting Digital Media to Mathematical Literacy
}

\author{
https://doi.org/10.3991/ijet.v15i03.11674 \\ Lingga Nico Pradana ${ }^{(凶)}$, Octarina Hidayatus Sholikhah, Swasti Maharani \\ Universitas PGRI Madiun, Madiun, Indonesia \\ nicopgsd@unipma.ac.id \\ Muhammad Noor Kholid \\ Universitas Muhammadiyah Surakarta, Surakarta, Indonesia
}

\begin{abstract}
Digital media is currently a trend in learning mathematics. However, digitalization of the media in primary mathematics education still at an introductory level. This study aims to determine students' mathematical literacy abilities, supported by digital media. The digital media used in this study was Virtual Mathematics Kits (VMK). This study involved 83 primary school students (45 intervention class; 28 non-intervention class) as participant of mathematical literacy training ( 6 weeks). Students' mathematical literacy evaluated by two section mathematical literacy test. This study revealed that mathematical literacy training led to improve mathematical literacy from both classes. However, mathematical literacy training with VMK aplication have better performance. This study shows that VMK as the digital media have big impact to support students' mathematical literacy abilities.
\end{abstract}

Keywords - Digital media, Virtual Mathematics Kits (VMK), mathematical literacy

\section{Introduction}

\subsection{Applying the styles to an existing paper}

The digital era has entered the realm of education. Utilization of technology for education becomes an important thing [1]-[3]. However, the use of technology in elementary school mathematics education is still not created climate. Elementary school mathematics education requires the ability to analyze, reason, convey ideas, and solve problems in a variety of situations [4], [5]. All of these are generally referred to as mathematical literacy [6], [7]. Mathematical literacy is an important ability to support students' mathematical abilities [8], [9]. Therefore, it is important to review from the side of mathematics literacy of students to see the development of mathematical abilities.

Previous studies on mathematical literacy states that mathematical literacy is a skill that can be trained [9]-[11]. However, the research was conducted at higher school levels and has not been based on the ability of elementary school students. Research on 
mathematics literacy in elementary schools is mostly done using scientific learning models with concrete media [12]-[14]. However, there has not been any use of technology in the model and media used. To be able to understand and connect mathematical concepts, media needed to make mathematical objects dynamic and can be manipulated [15]-[17]. Based on this, VMK is designed to present mathematical objects to be dynamic and can be easily manipulated. This is expected to assist students in improving mathematical abilities in mathematical literacy.

Based on these issues, this study aims to show the effectiveness of VMK in mathematical literacy activities. Mathematical literacy activities are designed as extracurricular activities outside school hours. In this activity VMK was used to assist students in understanding, reasoning, making ideas and solving problems. With the use of VMK in mathematical literacy activities, students were expected to develop mathematical literacy skills and have experience in using technology through digital media.

\section{Methods}

\subsection{Participant}

The study involved 83 elementary school students from 4 schools in Madiun, Indonesia (mean age $=10.6$; range age $=9.8-11.3 ; 37$ males; 46 females). Students come from schools that use the 2013 curriculum. The selection of schools is based on the average national exam scores in the last three years. The selected school is a medium level school (interval mean score $=6.7 \leq \bar{X} \leq 7.7$ ). 83 students were divided into two classes, namely intervention classes and non-intervention classes. The intervention class consisted of 45 students and the non-intervention class consisted of 38 students. An intervention class is a class where VMK is used.

\subsection{Material}

The instrument used in this study was a mathematical literacy instrument. The mathematical literacy instrument was divided into two test sessions (S1 and S2). The instrument was in the form of 30 multiple choice item questions ( 15 items for each session). Each item is given a reason column to write the reason for the answer chosen (see Figure 1). The maximum score obtained is 60 . Mathematical literacy instruments are based on mathematical literacy indicators [4]. The reliability coefficient for each test was 0.73 (S1) and 0.76 (S2).

\subsection{The use of VMK and the structure of mathematical literacy activities}

VMK is a collection of products from various software such as geogebra, matlab and office mix. The purpose of VMK is to:

- Present mathematical problems

- Transforming mathematical concepts into an object that can be manipulated 
- Provide assistance (slimulus) to students to make ideas of problem solving.

VMK was created to support mathematical literacy activities. Sample of VMK presented in Figure 1. Mathematical literacy activities are designed as extracurricular activities conducted outside school hours. This activity is carried out for 90 minutes every week in a 6-week period. Mathematical literacy activities are carried out in collaboration with class teachers. Summary of mathematical literacy activities presented in Table 1.

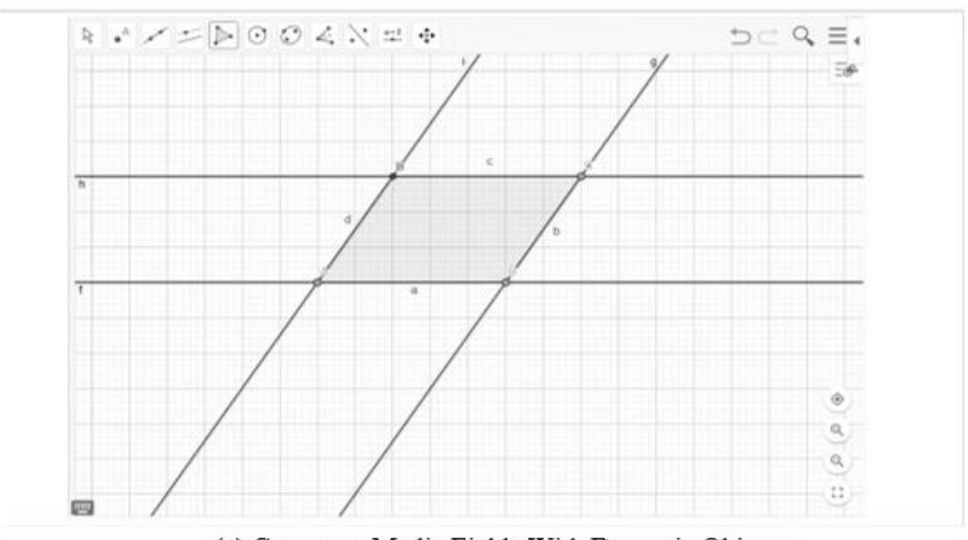

(a) Geometry Media Fields With Dynamic Objects
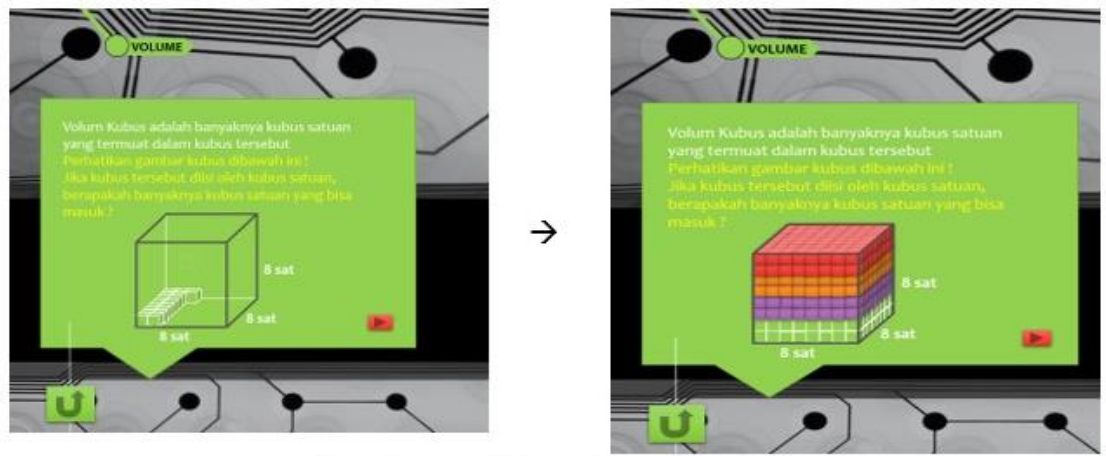

(b) Animated Volume Cubes with unit Cubes

Fig. 1. Sample of VMK

Table 1. Summary of Mathematical Literacy Activities

\begin{tabular}{|c|l|}
\hline Weeks & \multicolumn{1}{c|}{ Objective } \\
\hline 1 & Formulate and formulate mathematical problems \\
\hline $2-3$ & Reasoning and making ideas for completion \\
\hline $4-5$ & Apply, present and evaluate matters relating to mathematical problems \\
\hline 6 & Integrating activities \\
\hline
\end{tabular}




\subsection{The use of VMK and the structure of mathematical literacy activities}

The $\mathrm{S} 1$ test was administered 2 weeks before the mathematical literacy activity is carried out. Students must complete a S1 test for 60 minutes. A week after math literacy activities are completed, S2 test administered to students. The time given was 60 minutes.

\section{Result and Discussion}

The results of the study are presented in two parts, consistency in the design of mathematical literacy activities and the effectiveness of VMK in mathematical literacy activities. Data on the S1 test were analyzed with ANOVA to show consistency in mathematical literacy activities before the intervention. Data representing VMK effectiveness (S2 test) were analyzed using ANCOVA [18], [19]. The means and standard deviations presented in Table 2.

Table 2. Means and standard deviations

\begin{tabular}{|l|c|c|c|c|}
\hline \multirow{2}{*}{ Test } & \multicolumn{2}{c|}{ Intervensi (45) } & \multicolumn{2}{c|}{ Non-intervensi (38) } \\
\cline { 2 - 5 } & $\boldsymbol{M}$ & $\boldsymbol{S D}$ & $\boldsymbol{M}$ & $\boldsymbol{S D}$ \\
\hline S1 test & 37.42 & 8.04 & 37.81 & 8.52 \\
\hline S2 test & 43.47 & 7.64 & 40.07 & 8.31 \\
\hline
\end{tabular}

\subsection{Consistency in the design of mathematical literacy activities}

The results of the ANOVA stated that there were no significant mean differences between the intervention class and the non-intervention class $F(1.82)=2.46, p=0.16$. Therefore, the mathematical literacy ability of students before the intervention is no different. The consistency of the design of mathematical literacy activities becomes very important. With the conclusion that the mathematical literacy ability of students before the intervention is not different, the differentiator of the two classes after the activity ends is the use of VMK.

\subsection{The effectiveness of VMK in mathematical literacy activities}

ANCOVA with S1 test scores as covariates was performed to determine differences in mean scores of mathematics literacy tests (S2) between intervention and non-intervention classes. S1 test scores are used as covariates because they are a control of early mathematical literacy abilities. Furthermore, the mean difference is seen by paying attention to $p$ values. In the ANCOVA results it was stated that there were significant mean differences between the two classes $F(1.82)=8.34, p<0.01$. The mean difference is presented in Figure 2. Figure 2 also shows an increase in the average in the two classes. However, the intervention class has a better average than the non-intervention class. The conclusion obtained is that students who use VMK in mathematical literacy 
activities have better mathematical literacy skills. VMK as a digital media has proven effectiveness value to support mathematics literacy-based activities.

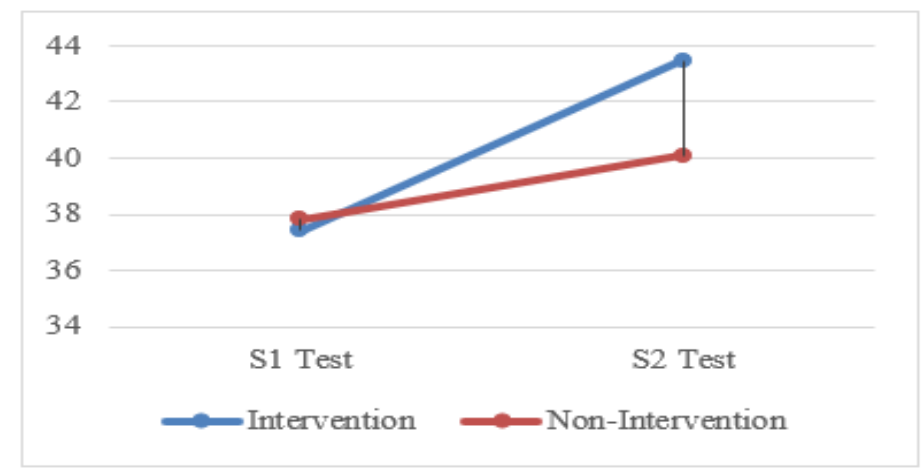

Fig. 2. Means S1 \& S2 Test of Mathematical Literacy

This research shows the role of digital media that supports mathematical literacybased activities. Computer-based activities are highly correlated with mathematical literacy activities [20]. The findings of this study state that VMK can provide assistance for students in solving mathematical problems. Unlike the use of concrete objects in learning mathematics literacy [12], [21], VMK makes mathematical objects manipulated. Mathematical objects become dynamic. This makes students freely explore mathematical concepts and look for relationships between concepts. From the perspective of mathematical literacy, mathematical literacy activities are carried out outside school hours. This activity is designed as an extracurricular activity. Unlike the integration of mathematical literacy in learning [12], [14], [22]-[24], this activity is free from mathematics learning objectives in class. That makes mathematics literacy activities can focus on the goals or objectives of mathematical literacy abilities [4]. VMK on this activity was created specifically to assist students in achieving mathematical literacy objectives. The problems presented in VMK also vary without being tied to the mathematics curriculum in schools. Thus, students not only get the experience of learning mathematics literacy. Students get an introduction to technology which is certainly very important in the digital age [2].

From the perspective of using VMK, students are very enthusiastic in using VMK in mathematics literacy classes. Although this digital media is new media, students have a high interest in media. Some students have difficulty in using VMK especially in geometry media. But the activity continued to run smoothly because teachers and researchers helped students in using VMK. VMK makes students easier to do reasoning. Once again a dynamic object is very helpful for students in finding ideas of problem solving [25]. As shown in Figure 3, students manipulate the parallelogram structure into various other forms of parallelogram. At a certain moment, students can form a square or rectangle. This allows students to connect the concept of parallelogram to the concept of square or rectangular. 

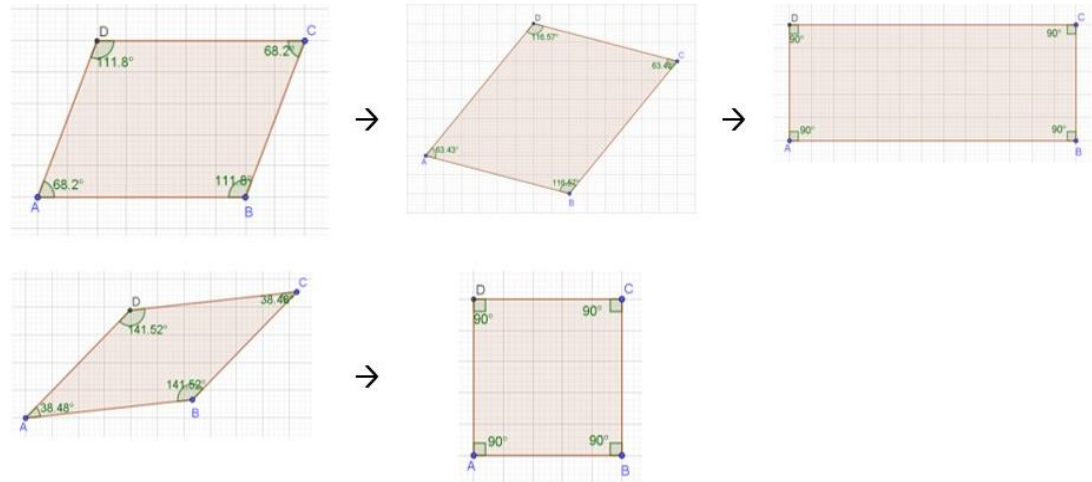

Fig. 3. Sample Student Worksheet

\section{Conclusion}

This study concludes that the use of digital media such as VMK can support mathematical literacy activities. Students who are involved in mathematical literacy activities indeed experience an increase in mathematical literacy abilities. However, VMK can assist students in learning mathematical literacy. Students can learn mathematics literacy easily and optimally. The most important thing in a mathematical media is the ability to present abstract concepts in the form of a kongket. VMK is able to provide and present forms that are not only concrete but also dynamic and manipulative. Therefore, in mathematical literacy-based activities it is strongly recommended for teachers to use digital media. In this case VMK itself.

This study has several limitations. The first limitation is the absence of an introduction to VMK before the start of mathematical literacy activities. This makes it difficult for some students to use VMK. Therefore, it is very important to introduce VMK before the activity is carried out. The second limitation, the subject of this study is in the same class that is class 5 . Because the use of VMK is able to support mathematical literacy activities, it is therefore very important to involve more levels and form a more heterogeneous group.

\section{Acknowledgement}

The authors wish to thank to participant, teacher, and school were support for this study.

\section{References}

[1] P. Akayuure, K. S. Asiedu-Addo, and V. Alebna, "Investigating the Effect of Origami Instruction on Preservice Teachers' Spatial Ability and Geometric Knowledge for 
Teaching," Int. J. Educ. Math. Sci. Technol., vol. 4, no. 3, pp. 198-209, 2016. https://doi.org/10.18404/ijemst.78424

[2] A. A. Genlott and Å. Grönlund, "Closing the gaps - Improving literacy and mathematics by ict-enhanced collaboration," Comput. Educ., vol. 99, pp. 68-80, 2016. https://doi.org/10.101 6/j.compedu.2016.04.004

[3] L. Sugandi and Y. Kurniawan, "The influence of information technology on the information and service quality for the teaching and learning," Int. J. Emerg. Technol. Learn., vol. 13, no. 12, pp. 230-237, 2018. https://doi.org/10.3991/ijet.v13i12.8665

[4] OECD, PISA 2012 Assessment and Analytical Framework. OECD Publishing, 2012.

[5] D. Williams and A. Kluev, "The Entrepreneurial University: Evidence of the Changing Role of Universities in Modern Russia," Ind. High. Educ., vol. 28, no. 4, pp. 271-280, 2014. https://doi.org/10.5367/ihe.2014.0212

[6] C. Julie, "Learners' Context Preferences and Mathematical Literacy," Math. Model., pp. 195-202, Jan. 2007. https://doi.org/10.1533/9780857099419.4.195

[7] J. de Lange, "Mathematics for Literacy," in Quantitative Literacy: Why Numeracy Matters for Schools and Colleges, 2003, pp. 75-90.

[8] K. Lengnink, "Reflecting mathematics: An approach to achieve mathematical literacy," ZDM - Int. J. Math. Educ., vol. 37, no. 3, pp. 246-249, 2005.

[9] L. D. Yore, D. Pimm, and H. L. Tuan, "The literacy component of mathematical and scientific literacy," Int. J. Sci. Math. Educ., vol. 5, no. 4, pp. 559-589, 2007. https://doi.org/ 10.1007/s10763-007-9089-4

[10] T. Ehmke, E. Wild, and T. Müller-Kalhoff, "Comparing adult mathematical literacy with PISA students: Results of a pilot study," ZDM - Int. J. Math. Educ., vol. 37, no. 3, pp. 159_ 167, 2005. https://doi.org/10.1007/s11858-005-0005-5

[11] F. Haara, O. Bolstad, and E. Jenssen, "Research on mathematical literacy in schools - Aim, approach and attention," Eur. J. Sci. Math. Educ. Math. Educ., vol. 5, no. 3, pp. 285-313, 2017.

[12] T. Hofer and A. Beckmann, "Supporting mathematical literacy: examples from a crosscurricular project," ZDM Math. Educ., vol. 41, pp. 223-230, 2009. https://doi.org/10.100 7/s11858-008-0117-9

[13] H. Y. Mumcu, "Using Mathematics , Mathematical Applications , Mathematical Modelling , and Mathematical Literacy: A Theoretical Study," J. Educ. Pract., vol. 7, no. 36, pp. 8096, 2016.

[14] S. Sumirattana, A. Makanong, and S. Thipkong, "Using realistic mathematics education and the DAPIC problem-solving process to enhance secondary school students ' mathematical literacy," Kasetsart J. Soc. Sci., vol. 38, no. 3, pp. 307-315, 2017. https://doi.org/10.101 6/j.kjss.2016.06.001

[15] J. Hwang, K. M. Choi, Y. Bae, \& Dong, and H. Shin, "Do Teachers' Instructional Practices Moderate Equity in Mathematical and Scientific Literacy? An Investigation of the PISA 2012 and 2015," Int J Sci Math Educ, 2018. https://doi.org/10.1007/s10763-018-9918-7

[16] V. N. Tariq, P. Qualter, S. Roberts, Y. Appleby, and L. Barnes, "Mathematical literacy in undergraduates: role of gender, emotional intelligence and emotional self-efficacy," Int. J. Math. Educ. Sci. Technol., vol. 44, no. 8, pp. 1143-1159, 2013. https://doi.org/10.1080/0 020739x.2013.770087

[17] J. Colwell and M. C. Enderson, “" When I hear literacy ': Using pre-service teachers ' perceptions of mathematical literacy to inform program changes in teacher education," Teach. Teach. Educ., vol. 53, pp. 63-74, 2016. https://doi.org/10.1016/j.tate.2015.11.001

[18] D. Ary, L. C. Jacobs, C. K. Sorensen, and D. A. Walker, Introduction to Research in Education. 2014. 
[19] S. E. Maxwell and H. D. Delaney, Designing Experiments and Analyzing Data: A Model Comparison Perspective, Second Edition. New York: Routledge, 2018.

[20] U. Ic and T. Tutak, "Correlation between Computer and Mathematical Literacy Levels of 6th Grade Students," Eur. J. Educ. Res., vol. 7, no. 1, pp. 63-70, 2017.

[21] A. R. Gatabi, K. Stacey, and Z. Gooya, "Investigating grade nine textbook problems for characteristics related to mathematical literacy," Math. Educ. Res. J., vol. 24, no. 4, pp. 403421, 2012. https://doi.org/10.1007/s13394-012-0052-5

[22] F. M. Firdaus and T. Herman, "Improving primary students' mathematical literacy through problem based learning and direct instruction," Educ. Res. Rev., vol. 12, no. 4, pp. 212-219, 2017. https://doi.org/10.5897/err2016.3072

[23] N. Sudarwati and Rukminingsih, "Evaluating e-learning as a learning media a case of entrepreneurship e-learning using schoology as media," Int. J. Emerg. Technol. Learn., vol. 13, no. 9, pp. 269-279, 2018. https://doi.org/10.3991/ijet.v13i09.7783

[24] Y. Wang and W. Jiang, "An automatic classification and clustering algorithm for online learning goals based on cognitive thinking," Int. J. Emerg. Technol. Learn., vol. 13, no. 11, pp. 54-66, 2018. https://doi.org/10.3991/ijet.v13i11.9587

[25] B. Güven and T. Kosa, "The effect of dynamic geometry software on student mathematics teachers' spatial visualization skills," Turkish Online J. Educ. Technol., vol. 7, no. 4, pp. 100-107, 2008.

\section{$7 \quad$ Authors}

Lingga Nico Pradana is lecturer at Department of Primary Education Universitas PGRI Madiun, Madiun, Indonesia 63117. He is the editor of Premiere Educadum: Jurnal Pendidikan Dasar dan Pembelajaran. He works also on spatial literacy project on mathematics learning.

Octarina Hidayatus Sholikhah is lecturer at Department of Primary Education Universitas PGRI Madiun, Madiun, Indonesia 63117. She also works at Teacher Profession Education as IT expert. She is the editor of Premiere Educadum: Jurnal Pendidikan Dasar dan Pembelajaran.

Swasti Maharani is lecturer at Department of Mathematics Education Universitas PGRI Madiun, Madiun, Indonesia 63117. She is the editor of Jurnal Ilmiah Pendidikan Matematika (JIPM).

Muhammad Noor Kholid is lecturer at Department of Mathematics Education Universitas Muhammadiyah Surakarta, Surakarta, Indonesia 57162.

Article submitted 2019-09-14. Resubmitted 2019-10-21. Final acceptance 2019-10-18. Final version published as submitted by the authors. 